\title{
P53 PROTEIN AND ITS FUNDAMENTAL ROLE IN THE CELL CYCLE, APOPTOSIS AND CANCER
}

\author{
Leandro Lopes Nepomuceno $^{1^{*}}$, Jorge Luís Ferreira ${ }^{2}$, Vanessa de Sousa Cruz ${ }^{1}$, \\ Gabriela Hadler Gabriel ${ }^{1}$, Eugênio Gonçalves de Araújo ${ }^{1}$ \\ ${ }^{1}$ Departamento de Patologia, Laboratório Multiusuário de Cultivo Celular - EVZ/UFG, \\ Goiânia, GO \\ ${ }^{2}$ Laboratório de Melhoramento Animal, Núcleo Avançado de estudos, Pesquisa e Extensão \\ em Melhoramento Genético de Zebuínos (Napgem) - EMVZ/UFT, Araguaína, TO \\ *Autor correspondente: Leandro_lopes795@hotmail.com
}

Recebido em: 22/09/2018 - Aprovado em: 23/11/2018 - Publicado em: 03/12/2018 DOI: 10.18677/EnciBio_2018B64

\begin{abstract}
P53 is activated in response to DNA damage, hypoxia, oncogenesis expression to promote the cell cycle checkpoints, DNA repair, cell senescence and apoptosis. These activities are important for the suppression of tumor formation and mediate cellular responses that are related to the cell cycle control, being the key element and also the main obstacle to the suppression of tumors. A better understanding of the apoptotic mechanism of p53 may promote the development of in vitro and in vivo assays, contributing to improve cancer diagnosis and prognosis and also helping with the deployment of rational strategies that advance the treatment therapies. In this way, this review is intended to present the effects of p53 protein on cells and show how it works on the activation of specific genes to promote the cell control and regulation and clarify the mysteries evolving the cell regulation mediated by p53 protein.
\end{abstract}

KEYWORDS: Molecular biology; Transcription Factors; Cancer metabolism; Mutation; Oncogene.

\section{A PROTEÍNA P53 E SEUS PAPÉIS FUNDAMENTAIS NO CICLO CELULAR, APOPTOSE E NEOPLASIA}

\section{RESUMO}

A p53 é ativada em resposta a danos no DNA, hipóxia, expressão de oncogenese para promover os pontos de verificação do ciclo celular, reparação do DNA, senescência celular e apoptose. Essas atividades são importantes para a supressão da formação de tumores, bem como mediar respostas celulares relacionadas ao controle do ciclo celular, sendo uma peça chave e o principal obstáculo para a supressão de tumores. Uma melhor compreensão do mecanismo apoptótico da p53 pode favorecer o desenho de ensaios in vitro e in vivo, contribuir para melhoria do diagnóstico e prognóstico do câncer e aplainar caminhos para estratégias racionais que melhorem as terapias de tratamento. Diante do exposto, esta revisão da literatura tem o propósito de apresentar os efeitos da proteína p53 sobre as células, as condutas e ativação de genes específicos para controle e regulação celular, bem como esclarecer os mistérios evolvendo a regulação mediada por p53.

PALAVRAS-CHAVE: Biologia Molecular; Fatores de Transcrição; Metabolismo do câncer; Mutação; Oncogene. 


\section{INTRODUCTION}

In recent years, with technological advances, new techniques of analysis and molecular research have been developed and incorporated into the routine of research laboratories. This knowledge brings, increasingly, the understanding of the molecular mechanisms and structures responsible for the metabolic processes in a cell. The study of cancer cells benefits from these advances, because it is now possible to fully evaluate the particularities of genes that regulate cell cycle, DNA stability or even programmed death (SHAPIRO et al., 2013).

From the classic observations of Rudolph Wirchow in the second half of the nineteenth century, a range of activities related to oncogenic research have been generated to explain the relationship of genes to the onset of cancer and its associated genetic alterations. The onset of the neoplastic process has already been defined as a multi-step process and involves the accumulation of genetic alterations in the cells. In general, these changes activate oncogenes and inactivate tumor suppressor genes (SUVÀ et al., 2013).

In comparative studies, p53 deficiency was associated in about $75 \%$ of human cancers, and often associated with loss of function or mutations of this molecule (VOUSDEN, 2013; BOUAOUN et al., 2016). This protein is the most studied tumor suppressor and acts in response to various forms of cell stress which mediate a variety of antiproliferative processes (MICIAK; BUNZ, 2016).

P53 is activated in response to DNA damage, hypoxia, expression of oncogenesis to promote cell cycle checkpoints, DNA repair, cell senescence and apoptosis (GURPINAR; VOUSDEN, 2015). These activities are important for the suppression of tumor formation, as well as for mediating cellular responses related to cell cycle control, being a key element and the main obstacle to tumor suppression (GURPINAR; VOUSDEN, 2015).

One of the most studied areas in the research involves the ability of this protein to regulate apoptosis (CUNHA et al., 2014; GREEN et al., 2014). The first clue that p53 could trigger apoptosis came from a work that reintroduced p53 into myeloid cells deficient in the synthesis of p53. Subsequent studies have shown that endogenous p53 could exert control of apoptosis by analyzing the thymus cells of (genetically modified) knockout mice. In this case, p53 was required to induce radiation apoptosis, but not cell death induced by other stimuli (LOWE et al., 1993).

In addition to its role in tumor suppression, p53-dependent apoptosis contributes to cell death induced by chemotherapy (ZHANG et al., 2013). This was demonstrated for the first time in studies using genetically modified cells treated in vitro and in vivo (LOWE et al., 1993). It has been found that both senescence and apoptosis contribute to the action of the chemotherapeutic agent, increasing the sensitivity of the cancer cells to agents, significantly reducing the doses of chemotherapy, possibly decreasing its adverse side effects (ZHANG et al., 2013).

Some tumors are insensitive to chemotherapeutic agents and in some cases may acquire resistance and relapse. Although the loss of p53 function has been linked to this resistance (HOLOHAN et al., 2013), the overall contribution of p53 to chemotherapy sensitivity remains under discussion.

A better understanding of the apoptotic mechanism of p53 may favor the design of in vitro and in vivo assays, contribute to the improvement of cancer diagnosis and prognosis, and flatten paths to rational strategies that improve treatment therapies. In view of the above, this literature review aims to present the effects of the p53 protein on cells, the conduction and activation of specific genes for 
cell regulation and regulation, as well as to clarify mechanisms that evolve regulation mediated by $p 53$.

\section{P53 Structure}

The TP53 tumor suppressor gene is located in the chromosomal allele 17 and presents the gene coding required for the synthesis of a $53 \mathrm{kDa}$ nuclear phosphoprotein, which names the final product. The p53 unit is composed of 393 amino acids, and the final structure of the molecule is composed of four identical monomers, titled wildtype p53, characterizing its normal functioning. Each subunit contains a C-terminal regulatory domain, a tetramerization domain, essential for p53 activity, a DNA binding domain and an $\mathrm{N}$-terminal transactivation domain ( $\mathrm{HOU}$ et al., 2015).

The p53 monomers form tetramers by the association of the tetramerization domains. The p53 tetramer formed binds to DNA sequences, where it transforms specific genes, this binding being aided by a transcription factor capable of binding to the DNA in a specific manner, which increases the stability of p53 (figure 1). Several points have already been identified for the p53 transactivation along the human genome, with 65,572 fragments in 542 loci. In an overview, p53 demonstrates high diversity of biological activities, in addition to tumor suppression (WEI et al., 2006).

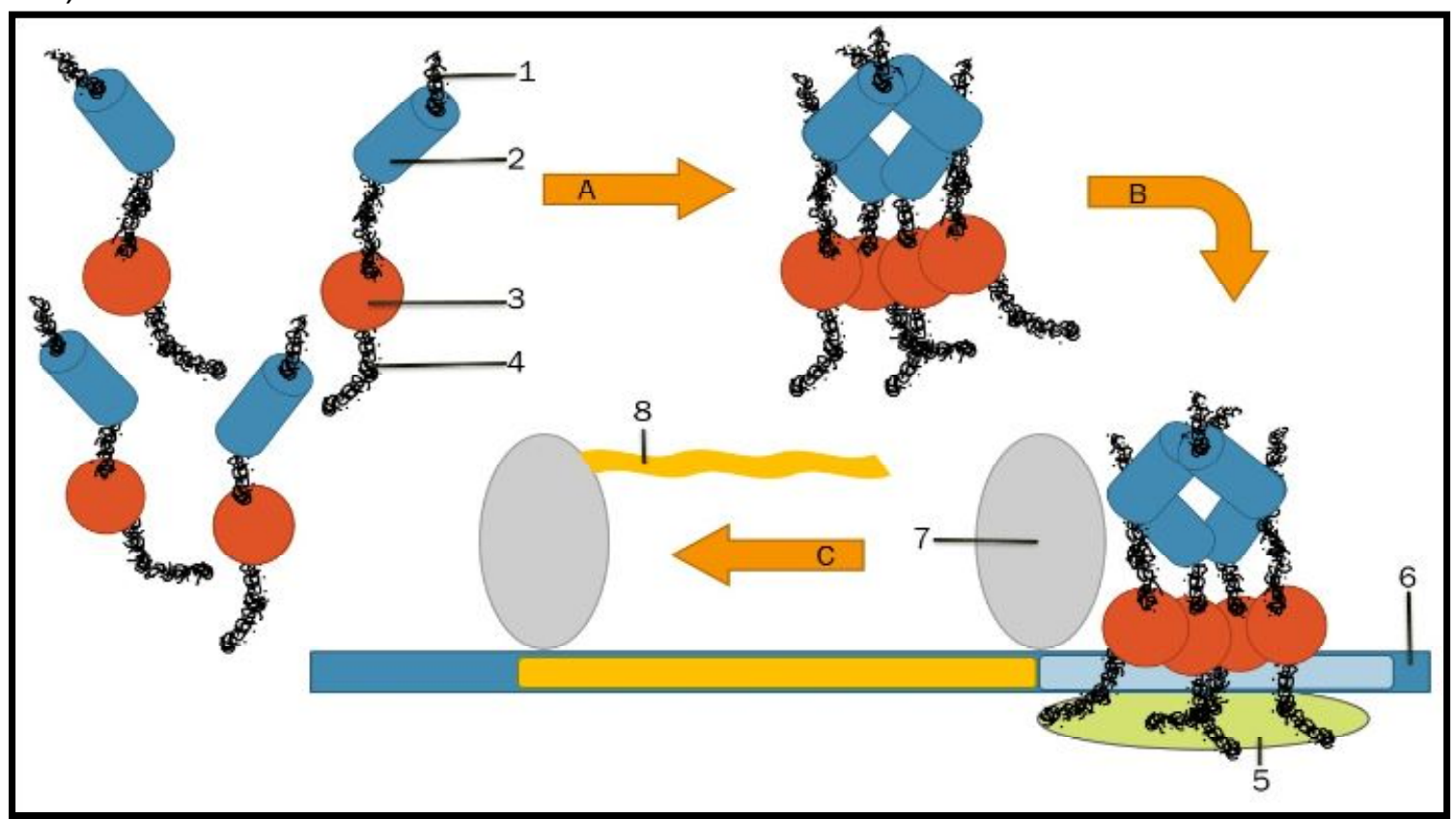

FIGURE 1 - Representation of the activation of p53 tetramer and the transactivation of target genes, contributing to the increase of specific proteins. 1) Cterminal domain of regulation; 2) Tetramerization domain; 3) DNA binding domain; 4) N-terminal transactivation domain; 5) Transcription factor; 6) DNA tape; 7) RNA polymerase; 8) RNA messenger; A) formation of p53 tetramer; B) Transactivation of target genes; C) Transcription.

source: self-published

Structural changes in the p53 protein are consequences of gene mutations, which generally promote the deactivation of the molecule. Because it is a tetramer, monomer units may exhibit changes in the overall structure or in specific subunits. Mutations found in cancer cells usually present changes in the DNA binding domain, which makes it impossible for the protein to bind to its specific targets, and prevents the activation of this gene (BOUAOUN et al., 2016). 
The changes that reflect in the loss of the function are, in general, of recessive character. These changes do not destroy the modified cells, which add competitive advantage over the normal adjacent cells. In relation to dominant p53 mutations, they trigger changes in the cell that lead to a gain in function, commonly found in malignant tumors, such as the ability to break down the basement membrane or acquire the ability to evade the immune system (YUE et al., 2017).

\section{P53 Functions}

Tumor suppressors act to maintain tissue homeostasis by regulating metabolism and controlling cell division. In order to maintain this homeostasis, several intrinsic and extrinsic processes act to regulate or prevent exacerbated cell proliferation (LEVINE ;PUZIO-KUTER, 2010; HONG et al., 2014). P53 acts in the control of these processes. For this reason, it can be called the "Guardian of the genome". Its main function is to monitor the integrity of the genome by recognizing DNA damage and assisting in its repair (GURPINAR; VOUSDEN, 2015).

Under normal conditions p53 levels are kept low by continuous degradation of p53 by MDM2 (murine double minute 2). In cellular stress conditions or in response to DNA damage the activation of a cellular homeostasis helper protein, ATM (ataxia telangiectasia mutated), acts directly on p53 that promotes its accumulation in the nucleus through the phosphorylation of the $\mathrm{N}$ - terminus of p53 ( WEBER; RYAN, 2015; LIU, L. et al., 2018).

With the increase of the active p53 concentration in the intranuclear region, there is formation of p53 dimers and, consequently, tetramers, the active and effector form of p53, which has the capacity to trigger specific target genes, which determine the cell cycle arrest during phases G1 / S, and acts on the G2 phase, inducing DNA repair; In this way, the intranuclear action of p53 is essential for cell cycle control (RETZLAFF et al., 2013; WOODS et al., 2015).

During phase $\mathrm{G} 1$, p53 promotes transcription of the TP21 gene, a process that stimulates gene transcription and induction of a $21 \mathrm{kDa}$ protein, whose function is to inhibit the action of cyclin-dependent kinases (CDKs), which cells in G1 until complete DNA repair (ARORA et al., 2015). Simultaneously, p53 activates the $45 \beta$ gene (GADD45 $\beta$ - Growth Arrest DNA Damage Inducible), acting on DNA repair. If the repair process fails or chromosome damage is very extensive, p53 activates genes involved in cell apoptosis (HAN et al., 2003).

However, if the final destination of the cell is apoptosis, p53 will trigger different stimuli, which will act in distinct metabolic pathways, in particular two pathways: extrinsic and intrinsic apoptotic pathways, each path being dependent on specific proteins and genes for its activation (FULDA; DEBATIN, 2006).

\section{Extrinsic pathway}

P53 can activate the extrinsic apoptotic circuit by inducing genes that encode membrane proteins, Fas (cell surface death receptor), DR5 (death receptor 5) and PERP (p53 apoptosis effector related to PMP-22), process of injury suffered by the cell. The Fas cell surface receptor is a member of the TNF receptor family (Tumor Necrosis Factor), being a key component for extrinsic cell death. In response to irradiation or extreme DNA damage, p53 transforms the Fas gene and increases Fas levels on the cell surface, allowing rapid cell sensitization to apoptosis (BONAVIDA, 2014; LIU et al., 2014).

Fas, in turn, allows the recruitment of two signaling proteins, FADD (Fasassociated death domain) and pro-caspase-8, forming the DISC (Death-inducing signaling complex) complex. After its recruitment, pro-caspase-8 is transformed into 
active caspase- 8 and then released into the cytoplasm, where it directly activates caspases, such as caspase-3 (BONAVIDA, 2014).

The second p53 -induced receptor is DR5, also termed death receptor, actively promotes apoptosis after overexpression of p53 or by binding of TNF-related apoptosis inducers (TRAIL). DR5 is induced by p53 in response to DNA damage and, in turn, promotes cell death by activation of caspase-8 (LEE et al., 2014).

The apoptotic gene PERP is also transactivated by p53. Studies indicate that PERP-induced apoptosis is also mediated by the caspase-dependent pathway that acts on caspase-8 cleavage. Complete loss of PERP expression is associated with p53 mutations. Another important factor of this gene is its crucial role in cell-cell adhesion and tumor suppression, and can be used as a possible marker for cancer cells and possibly a gene related to cell invasion capacity (KONG et al., 2013).

\section{Intrinsic pathway}

The intrinsic apoptotic pathway is regulated by the Bcl-2 family, which regulates the release of cytochrome $\mathrm{c}$ from mitochondria. The Bcl-2 family comprises a vast network of pro-apoptotic proteins (stimulate or participate in the apoptosis process) and anti-apoptotic (inhibit or block the apoptosis process) (Mariño et al., 2014). Family members are classified as Bcl-2 domain homology $(\mathrm{BH})$, with $\mathrm{BH} 1$, $\mathrm{BH} 2, \mathrm{BH} 3, \mathrm{BH} 4$ and a transmembrane domain commonly found. Among the mentioned domains, $\mathrm{BH} 3$ is present in all members and is essential for heterodimerization (association of different proteins) between the members (PEIXOTO et al., 2015).

In general, the Bcl-2 family can be divided into three subgroups. The first includes anti-apoptotic proteins, responsible for maintaining cell integrity and blocking apoptosis. Bcl-2, Bcl-XL, having the $\mathrm{BH} 1, \mathrm{BH} 2, \mathrm{BH} 3$ and $\mathrm{BH} 4$ domains belong to this group. The second subgroup belongs to a group of pro-apoptotic proteins, which induce or give continuity to the apoptotic cascade. Bax, Bak, Bok and Bcl-Rambo are the proteins belonging to this subgroup, characterized by presenting the $\mathrm{BH} 1, \mathrm{BH} 2$ and $\mathrm{BH} 3$ domains. The latter subgroup also has pro-apoptotic function. It is composed of an increasing number of proteins, classified as BH3-only proteins, because they present only one activation domain. In this group, the proteins Bad, Bid, Noxa, PUMA, Bmf (BOUMELA et al., 2014; MOYA et al., 2016).

Of the members of the Bcl-2 family, Bax was the first to be induced by p53. These proteins are found in the cellular cytoplasm in the form of monomers, a condition to which the molecule is inactivated. To perform their functions, Bax proteins need to be activated and translocated to the mitochondrial outer membrane (SUBBURAJ et al., 2015). In response to cellular stress activation, Bax forms homodimers, an association of two identical subunits, and induces the release of cytochrome c from mitochondria, through pores formed in the outer mitochondrial membrane, which results in the activation of caspase-9, being an action irreversible, triggering apoptosis ( WALENSKY; GAVATHIOTIS, 2011; MAES et al., 2017).

Another protein acting on the mechanism of cellular apoptosis, called PUMA, has as an auxiliary function in mitochondrial alterations in many tumor cell lines during the process of p53-dependent apoptosis. This molecule has two functions, to translocate the Bax protein to the mitochondrial membrane and to promote the quaternary structural arrangement for Bax activation (LIU et al., 2003; YU; ZHANG, 2008; RENAULT et al., 2015).

Recent studies have demonstrated the suppressive effect of $\mathrm{Bcl}-2$ antiapoptotic receptors, such as $\mathrm{Bcl}-2$ and $\mathrm{Bcl}-\mathrm{XL}$, when binding via its $\mathrm{BH}$-only domain 
to PUMA suppresses the effect of $\mathrm{Bcl}-2$ and releases the protein Bax, thereby altering the Bcl-2 / Bax ratio leading to apoptosis ( LI et al., 2015; CHEN et al., 2016).

In a study with mice deficient in Bax production, the normal apoptotic process in thymocytes was observed after induction of DNA damage, suggesting the existence of at least one other gene necessary to explain p53-dependent apoptotic response (ODA et al., 2000).

The Noxa gene was identified and classified, belonging to the Bcl-2 family, with BH3-only domain, which acts in a similar way to PUMA, inducing apoptosis through the association of the BH3-only domain with anti-apoptotic receptors. However, this mechanism does not fully explain its function, but probably Noxa and other p53 target genes cooperate for the efficient induction of apoptosis in various cell types ( ODA et al., 2000; MEISTER et al., 2016).

Mitochondria play a key role in the description of cell death and its mechanisms of regulation. Specific events such as hypoxia, trauma, temperature and radiation represent an important initial step essential to induce the process of cellular apoptosis. The mechanism that governs the control of apoptosis over mitochondria is established by the interaction of p53 with Bcl-2 family proteins (GALLUZZI et al., 2012).

In general, the process of apoptosis begins with the induction of membrane permeability of the mitochondria, with release of cytochrome $c$ to the cytosol. This process is controlled by proteins belonging to the Bcl-2 family. When an apoptotic stimulus is triggered, pro-apoptotic proteins such as Bax, Noxa or PUMA are transferred to the outer mitochondrial membrane to form a channel, which allows cytochrome c to exit (GALLUZZI et al., 2012; KALE et al., 2018).

In the cytosol, there is formation of the apoptossome, a complex formed from cytochrome $\mathrm{c}$ and APAF-1. This complex promotes the cleavage of procaspase-9, which in turn has the ability to activate effector caspases (Figure 2) (LANGLAIS et al., 2015).



FIGURE 2 - Representation of apoptosomal formation mechanism and activation of caspase effector. 1) Mitochondria; 2) Cytochrome c; 3) APAF-1 protein; 4) pro-caspase-9; 5) Apoptossome; 6) pro-caspase-3; 7) caspase-3 activated; A) Activation of the APAF-1 protein; B) Formation of the apoptosomal complex; C) Activation of Pro-caspase-3.

source: self-published 


\section{Activation of caspases}

Apoptotic caspases are classified as primers or executors, depending on their point of entry into the apoptotic cascade. Initiating caspases are the first proteins to be activated to determine cell death, which contribute to the first phase to trigger a cascade of reactions which generally consists of at least two stages until the activation of the caspases (KALLENBERGER; LEGEWIE, 2012).

Caspases present lethal action on the cell. To ensure the production and packaging of these proteins safely, without causing accidental death, they are produced and stored in their latent form (zymogens), and a specific event must occur to activate them. Activation of the initiating and executing caspases is totally distinct and dependent on specific stimuli such as oxygen reactive species, energy deficiency, DNA damage and hypoxia (MAZZONI; FALCONE, 2008; REDZA; AVERILL, 2016).

In general, the activation of the caspases requires dimers of identical catalytic units and highlighting that each catalytic unit has its active site. The basic structures of the caspases are presented with two major subunits, titled large and small subunits. Its activation consists of cleavage of the caspase and the rearrangement of the dimers by the binding of its subunits within its binding region (Figure 3) (CLARK, 2016; DAGBAY; HARDY, 2017).

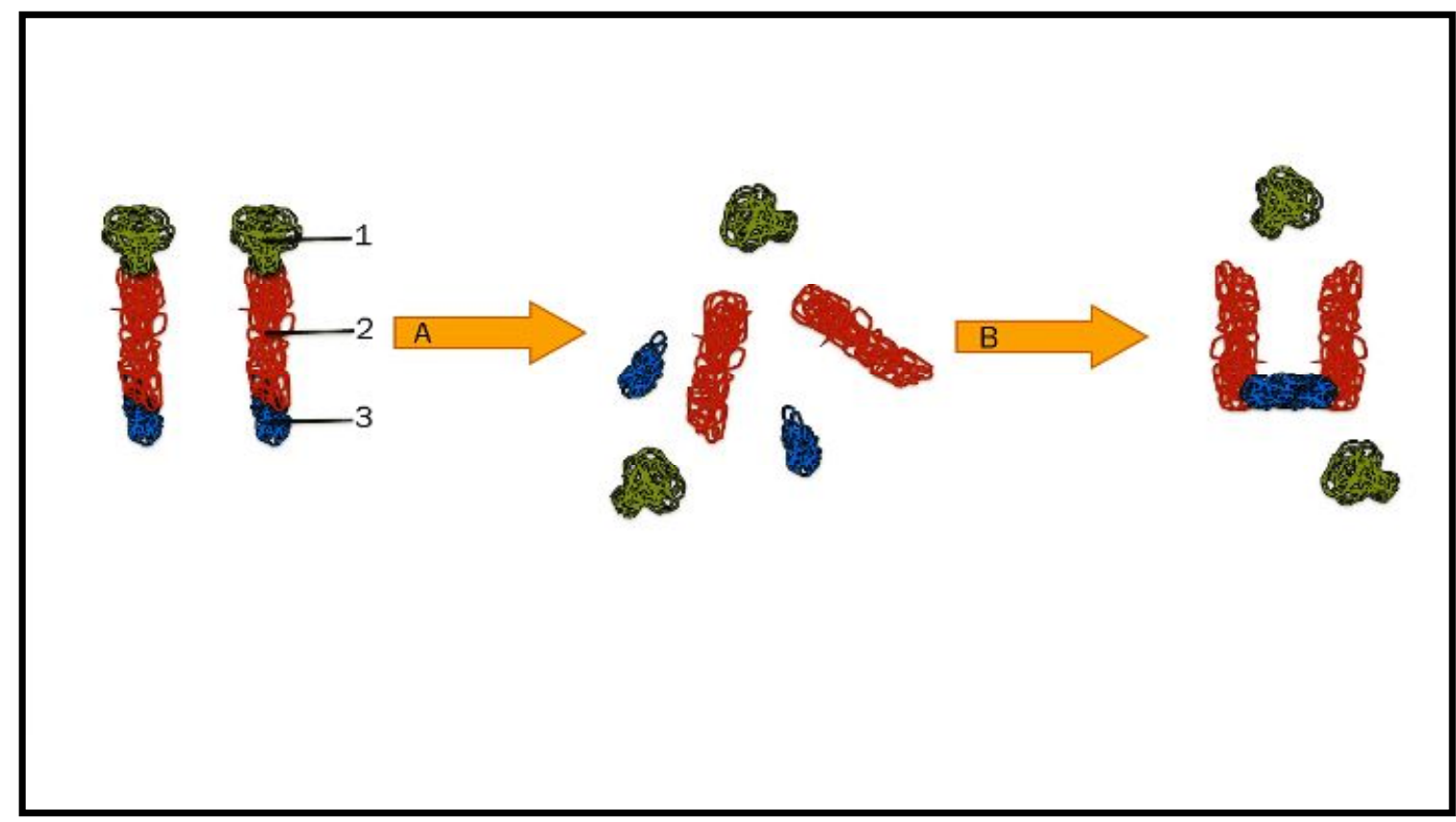

FIGURE 3 - Representation of the mechanism of generalized activation of the caspases from the reorganization of the dimers. 1) Pro domain CARD; 2) large subunit; 3) small subunit; A- Reorganization of the dimers; BActivation of caspase.

source: self-published

Caspases can be divided and grouped depending on the origin of the cell death stimulus. Caspases belonging to the intrinsic pathway, caspase- 9 and caspase-2, respond to changes in mitochondrial potential, while caspase-8 and caspase-10 belong to the extrinsic pathway and are activated by death receptors. These initiator caspases cleave the pro-enzyme forms of effector caspases 
(caspase-3, caspase-6 and caspase-7), which allow the digestion of essential targets, which affect cell viability (MCILWAIN et al., 2013).

\section{Control of p53 expression}

P53 is a very important protein to maintain cell functionality. Because it is a molecule with potential for high cell control and with the capacity to cause important changes in cellular functioning, the mechanism of control of its expression must be effective; therefore, the processes used to regulate p53 expression include its degradation, blocking its activation and blocking p53 tetramer formation (CUNHA et al., 2014).

One of p53's main functions is its direct relationship with the central mechanism of cell growth by directly influencing mitosis. It has already been shown that the accumulation of p53 in cardiomyocytes caused apoptosis of the fibers, and in turn developed the process of cardiac insufficiency (MAZELIN et al., 2016). The MDM2 oncogene is of great importance in suppressing p53, and exerts a function similar to the protein ubiquitin ligase E3 (YUE et al., 2017).

MDM2 is able to inhibit p53 protein activity through three pathways. The first is by blocking p53 through its association in the transactivation domain, which forms the MDM2 / p53 complex and inhibits its transcriptional activation. The second process is to promote the transport of p53 to the cytosol by regulating the intranuclear p53 concentration by means of negative feedback. The latter process occurs in the cellular cytoplasm, where MDM2 plays its role of proteolysis via ubiquitin and proteosal degradation (Figure 4) ( PANT; LOZANO, 2014; NIHIRA et al., 2017 ).

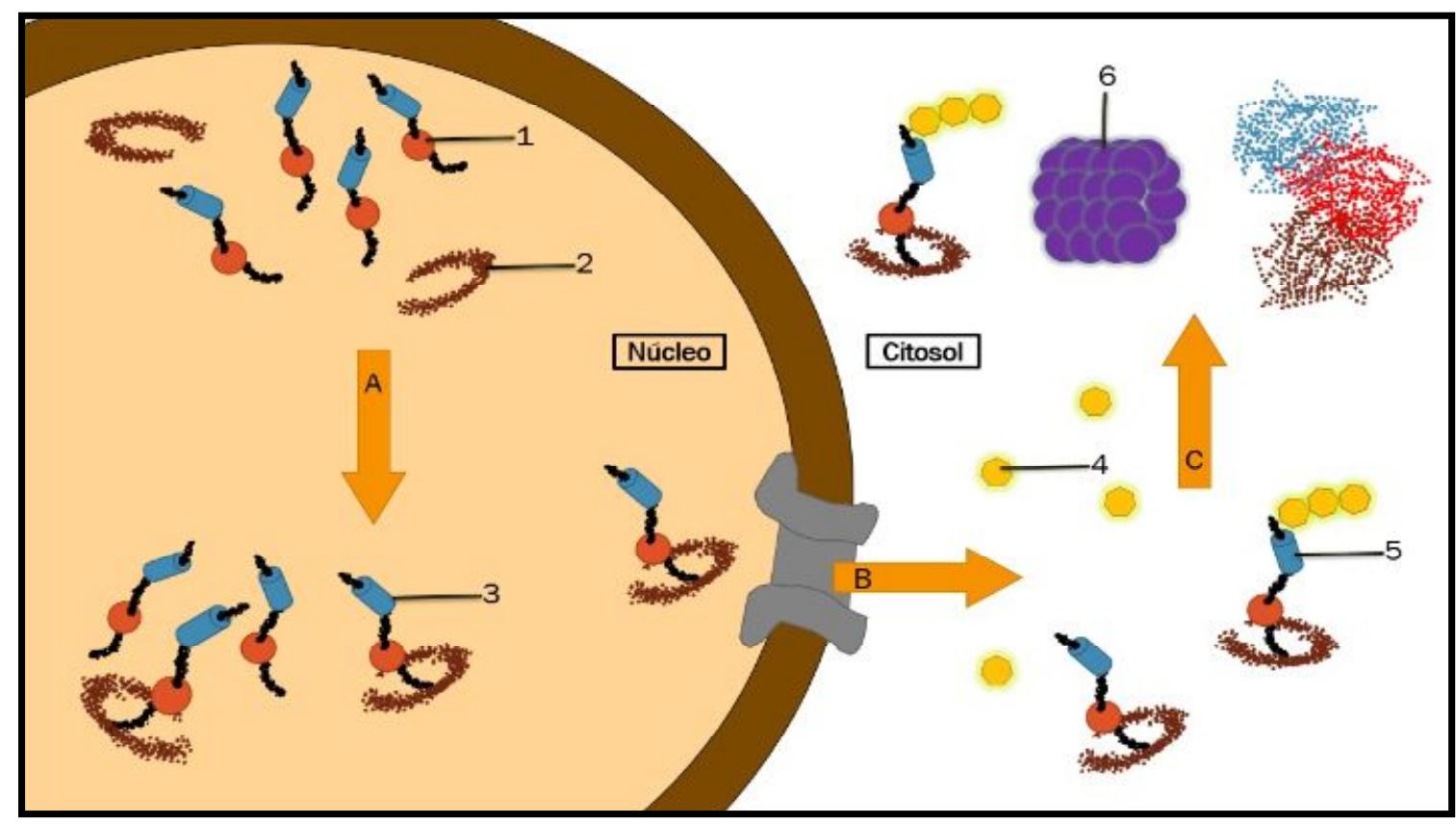

FIGURE 4 - Representation of the control mechanism of p53 regulated by the MDM2 protein. 1) p53 protein; 2) MDM2 protein; 3) MDM2 / p53 complex; 4) Ubiquitin; 5) Conjugate of ubiquitin; 6) Proteasome; A) Blocking p53; B) Transport of $\mathrm{p} 53$ to the cytosol; C) Ubiquitination of proteins.

source: self-published

Experiments with MDM2 control have shown that this is the main negative regulator of p53, since the increase in its expression blocks p53 and promotes the 
advancement in the cell cycle. In experiments with pigs, when inoculating PRRSV (swine reproductive and respiratory syndrome virus), there was an increase in MDM2 concentration, inducing cell replication and consequently virus replication, avoiding apoptosis cell death in the initial phase of infection (WANG et al., 2016).

\section{Inactivation of $\mathrm{p} 53$}

Inactivation of p53 protein may occur in the following situations: gene alterations, interactions of p53 with suppressor proteins and protein interactions with viral proteins. Among the cited cases, the most studied is the genetic alteration due to chromosomal mutations and gene deletion (WADE et al., 2013).

Point mutations and the exchange of one or more nucleotides are the most common types of gene changes found in neoplasms, which results in the formation of a non-functional protein. These mutations trigger metabolic changes in the cell, interrupt cell cycle arrest, and prevent DNA check and repair (HIENTZ et al., 2017).

Several researchers have demonstrated the importance of p53 in evaluating tumors where p53 deficiency is present. In the case of Li-Fraumeni syndrome, patients inherit the mutant gene in the TP53 allele, which predisposes them to develop cancer at an early age, such as sarcomas, breast cancer, leukemias, lymphomas and brain neoplasms, which are commonly reported in these patients. There are reports that mention the possibility of any type of tumor occurring in the absence of the TP53 gene. During the development of the neoplasm, the TP53 mutation, whether spontaneous or inherited, results in complete p53 deficiency and, consequently, loss of function (MACEDO et al., 2016).

\section{Double nature of p53 and cancer}

It is known that the functions of regulation of apoptosis, cell cycle arrest and senescence are essential for tumor suppression. However, its tumor suppression function can be summarized in transcription and induction of pro-apoptotic genes in response to DNA damage (DITCH; PAULL, 2012; GURPINAR; VOUSDEN, 2015). The neoplasia arises through a process where the somatic mutations of cellular genes occur, followed by a clonal selection of the progeny variant with aggressive growth properties (CALVINO, 2016).

In the normal cell, the p53 protein has a short half-life, which may last minutes before its degradation, being undetectable by immunohistochemistry (IHC). Despite this, there are reports that this protein was expressed in extremely weak reactions ( ESRIG et al., 1993; CAMPOS et al., 2014). Some mutations of the TP53 gene generally express altered proteins with a longer half-life, which explains why they are detectable by IHC (PAGLIARONE et al., 2016).

In works with carcinogenic cells obtained from prostate from dogs, mutated p53 was detected through $\mathrm{IHC}$, even with the variation of the protein, its epitopes are present and its expression is possible, however, its function is compromised by the mutation present in the TP53 gene (PAGLIARONE et al., 2016).

With the identification of p53 functions, another approach was questioned on the hypothesis that p53 is a tumor-inducing agent. Some p53 mutants may aggregate other effects on the cell, such as the ability to invade other tissues or deregulate cell growth. Thus, they lose the ability to suppress tumor and contribute to tumor progression (MULLER; VOUSDEN, 2014; SCHULZ; MOLL, 2018).

This dual nature of p53, protective and cell death, indicates the possibility that p53 may also act as a tumor promoter. The anti-apoptotic function of p53 may 
lead to the survival of damaged cells under mutated conditions, which may increase the possibility of malignant transformation. As found in the research, a new mutation of p53 has been reported, these alterations promote the transactivation of genes not normally recognized, in this way they induce the formation of proteins that block cell membrane receptors, they normally signal the apoptosis via extrinsic, thus mocking the immune system by transcribing and activating survival genes (MONTEITH et al., 2016).

In humans approximately $75 \%$ of the mutations found in p53 are missense, which consists of nucleotide substitution, resulting in amino acid exchange. These changes, even if small, can promote the formation of an altered protein, which generates a selective advantage rather than losing function completely (BROSH; ROTTER, 2009). Studies on rodents with mutant p53 have developed larger tumors and about three times more tumors, which emphasized the potential effects of a p53 mutation both on initiation and tumor progression (LUBET et al., 2000).

\section{Structural changes}

The structural alterations of p53 and its altered function arouse interests in the scientific community, aiming to clarify, under molecular vision, which point mutants can promote the development of the tumor, and thus to recreate models that more precisely explain the development of cancer (KATO et al., 2003).

According to the sequences of the mutations or the type of alteration generated in p53, they can be classified in two ways: for point alterations, which reflect from alterations in the DNA sequence and generating proteins with incorrect amino acid sequences. The second change observed is when the mutations are focused on the conformation of the molecule, making it impossible to fix the p53 in the DNA strand (ITOH et al., 2016).

The $\mathrm{N}$-terminal and $\mathrm{C}$-terminal domains are disordered structures, actively participating in the transactivation of other proteins and nonspecific binding of DNA. The DNA binding domain is well structured and responsible for DNA recognition, as noted, changes in DNA recognition domain favors changes in the molecule's conformations, changes in the $\mathrm{N}$ - and $\mathrm{C}$-terminal domains are related to the gain mutations of function (ITOH et al., 2016).

Among the structural changes, the $\mathrm{N}$-terminal and $\mathrm{C}$-terminal domains gain greater prominence regarding the ability to generate new oncogenic properties, as demonstrated in epithelial cells, the mutated p53 can transact specific genes responsible for cell adhesion, migration and proliferation of epithelial cells, adding functions to these cells (DONG et al., 2013).

These data imply that the positive regulation of the mutated p53 is responsible for the increase of the aggressiveness of tumors, in this way it induces a stimulation by the research in the control and regulation of $\mathrm{p} 53$, since it is involved in the prevention of the appearance of abnormal cells with capacity to cause tumors (WATANABE et al., 2014).

FINAL CONSIDERATIONS

The knowledge of the role of p53 in tumor suppression opens new doors to the scientific community and studies for the development of a possible control for cancer. The research innovates and deduces the pathways involved in p53-mediated cellular control and apoptotic activity. It also allows the discovery of possible solutions 
to maintain DNA integrity against deleterious aggressors, such as radiations and reactive oxygen species.

However, in-depth and increasingly specific investigations generate hypotheses that originate from existing models. This helps to refine the understanding of the role of p53 in tumor suppression as well as to understand the fact of p53 activity and its association with tumor suppression, or even to explain the innumerable variations found in relation to the mechanism of action of p53 in different cellular tissues.

New contexts and functions from p53 as a barrier to carcinogenesis have been identified in recent years, as shown by the various changes that have been observed in p53-deficient cells. The loss of its function not only causes increased cell division and improved cell survival, but also more invasive behavior and metabolic disorders, which have already been evidenced.

Future studies will provide the additional pieces needed to complete this complex molecular process, involving p53-mediated tumor suppression, which will allow us to better harness the power of this molecule from the perspective of cancer treatment.

\section{REFERENCES}

ARORA, S., TYAGI, N., BHARDWAJ, A., RUSU, L., PALANKI, R., et al. Silver nanoparticles protect human keratinocytes against UVB radiation-induced DNA damage and apoptosis: potential for prevention of skin carcinogenesis. Nanomedicine: Nanotechnology, Biology and Medicine, v. 11, n. 5, p. 1265-1275, 2015. Disponível em: < http://dx.doi.org/10.1016/j.nano.2015.02.024 >. doi: 10.1016/j.nano.2015.02.024.

BONAVIDA, B. NK cell phenotypic and functional heterogeneities and molecular mechanisms of cytotoxicity. Critical Reviews ${ }^{\text {TM }}$ in Oncogenesis, v. 19, n. 1-2, p. 21 25, 2014. Disponível em: http://www.dl.begellhouse.com/journals/439f422d0783386a,1495e1167ec31aaf,5251 c2e566890124.html >. doi: 10.1615/CritRevOncog.2014010804.

BOUAOUN, L., SONKIN, D., ARDIN, M., HOLLSTEIN, M., BYRNES, G., et al. TP53 Variations in Human Cancers: New Lessons from the IARC TP53 Database and Genomics Data. Human Mutation, 2016. Disponível em: < http://onlinelibrary.wiley.com/doi/10.1002/humu.23035/full >. doi: 10.1002/humu.23035.

BOUMELA, I., ASSOU, S., HAOUZI, D., DÉCHAUD, H., AIT-AHMED, O., et al. Developmental Regulated Expression of Anti-and Pro-Apoptotic BCL-2 Family Genes During Human Early Embryonic Development. Current medicinal chemistry, v. 21, n. 11, p. 1361-1369, 2014. Disponível em: < http://www.ingentaconnect.com/content/ben/cmc/2014/00000021/00000011/art00010

BROSH, R.; ROTTER, V. When mutants gain new powers: news from the mutant p53 field. Nature Reviews Cancer, v. 9, n. 10, p. 701-713, 2009. Disponível em: < http://www.nature.com/nrc/journal/v9/n10/abs/nrc2693.html >. doi: 10.1038/nrc2693.

CALVINO, B. Mécanismes physiopathologiques de la douleur des métastases osseuses. Douleurs: Evaluation-Diagnostic-Traitement, v. 17, n. 3, p. 109-121, 
2016. Disponível em: < http://dx.doi.org/10.1016/j.douler.2016.01.003 >. doi: 10.1016/j.douler.2016.01.003.

CAMPOS, M., DUCATELLE, R., KOOISTRA, H. S., RUTTEMAN, G., DUCHATEAU, L., et al. Immunohistochemical expression of potential therapeutic targets in canine thyroid carcinoma. Journal of Veterinary Internal Medicine, v. 28, n. 2, p. 564-570, 2014. Disponível em: < http://onlinelibrary.wiley.com/doi/10.1111/jvim.12330/full >. doi: $10.1111 /$ jvim.12330.

CHEN, C., QINCAO, L., XU, J., DU, S., HUANG, E., et al. Role of PUMA in methamphetamine-induced neuronal apoptosis. Toxicology letters, v. 240, n. 1, p. 149-160, 2016. Disponível em: < http://dx.doi.org/10.1016/j.toxlet.2015.10.020 >. doi: $10.1016 /$ j.toxlet.2015.10.020.

CLARK, A. C. Caspase Allostery and Conformational Selection. Chemical reviews, v. 116, n. 11, p. 6666-6706, 2016. Disponível em: < http://pubs.acs.org/doi/abs/10.1021/acs.chemrev.5b00540 >. doi: 10.1021/acs.chemrev.5b00540.

CUNHA, E. D. A.; BOURROUL, S.; COTRIN, S. S. Atividade da P53 no desenvolvimento do câncer. Atas de Ciências da Saúde, v. 2, n. 3, 2014. Disponível em: < http://www.revistaseletronicas.fmu.br/index.php/ACIS/article/download/579/701 >.

DAGBAY, K. B.; HARDY, J. A. Multiple proteolytic events in caspase-6 self-activation impact conformations of discrete structural regions. Proceedings of the National Academy of Sciences, v. 114, n. 38, p. E7977-E7986, 2017. Disponível em: < http://www.pnas.org/content/114/38/E7977.short >. doi: 10.1073/pnas.1704640114.

DITCH, S.; PAULL, T. T. The ATM protein kinase and cellular redox signaling: beyond the DNA damage response. Trends in biochemical sciences, v. 37, n. 1, p. 15-22, 2012.2 Disponível em: < http://www.sciencedirect.com/science/article/pii/S0968000411001617 >. doi: 10.1016/j.tibs.2011.10.002.

DONG, P., KARAAYVAZ, M., JIA, N., KANEUCHI, M., HAMADA, J., et al. Mutant p53 gain-of-function induces epithelial-mesenchymal transition through modulation of the miR-130b-ZEB1 axis. Oncogene, v. 32, n. 27, p. 3286-3295, 2013. Disponível em: < http://www.nature.com/onc/journal/v32/n27/abs/onc2012334a.html >. doi: $10.1038 /$ onc.2012.334.

ESRIG, D., SPRUCK 3RD, C. H., NICHOLS, P. W., CHAIWUN, B. E. N. J. A. P. O. R. N., STEVEN, K., et al. p53 nuclear protein accumulation correlates with mutations in the p53 gene, tumor grade, and stage in bladder cancer. The American journal of pathology, v. $143, \quad$ n. 5 , p. 1389-1397, 1993. Disponível em: < http://www.ncbi.nlm.nih.gov/pmc/articles/PMC1887166/ >.

FULDA, S.; DEBATIN, K. Extrinsic versus intrinsic apoptosis pathways in anticancer chemotherapy. Oncogene, v. 25, n. 34, p. 4798-4811, 2006. Disponível em: < 
http://www.nature.com/onc/journal/v25/n34/abs/1209608a.html 10.1038/sj.onc. 1209608.

GALLUZZI, L.; KEPP, O.; TROJEL-HANSEN, C.; KROEMER, G. Mitochondrial control of cellular life, stress, and death. Circulation research, v. 111, n. 9, p. 11981207, 2012. Disponível em: < http://circres.ahajournals.org/content/111/9/1198.short >. doi: 10.1161/CIRCRESAHA.112.268946.

GREEN, D. R.; GALLUZZI, L.; KROEMER, G. Metabolic control of cell death. Science, v. 345, n. 6203, p. 1250256, 2014. Disponível em: < http://science.sciencemag.org/content/345/6203/1250256?sso=1\&sso_redirect_count $=1$ \&oauth-code $=$ efe39697-f87f-430e-8d63-d905cdfd898d $>$. doi: 10.1126/science.1250256.

GURPINAR, E.; VOUSDEN, K. H. Hitting cancers' weak spots: vulnerabilities imposed by p53 mutation. Trends in cell biology, v. 25, n. 8, p. 486-495, 2015. Disponível em:

http://www.sciencedirect.com/science/article/pii/S0962892415000665 >. doi: 10.1016/j.tcb.2015.04.001.

HAN, C., DEMETRIS, A. J., MICHALOPOULOS, G. K., ZHAN, Q., SHELHAMER, J. $\mathrm{H}$., et al. PPARy ligands inhibit cholangiocarcinoma cell growth through p53dependent GADD45 and p21WAF1/Cip1 pathway. Hepatology, v. 38, n. 1, p. 167177 , 2003.

Disponível em:

$$
>\text {. }
$$
http://onlinelibrary.wiley.com/doi/10.1053/jhep.2003.50296/pdf 10.1053/jhep.2003.50296.

HIENTZ, K.; MOHR, A.; BHAKTA-GUHA, D.; EFFERTH, T. The role of p53 in cancer drug resistance and targeted chemotherapy. Oncotarget, v. 8, n. 5, p. 8921, 2017. Disponível em: < https://www.ncbi.nlm.nih.gov/pmc/articles/PMC5352454/ >. doi: 10.18632/oncotarget.13475.

HOLOHAN, C.; VAN SCHAEYBROECK, S.; LONGLEY, D. B.; JOHNSTON, P. G. Cancer drug resistance: an evolving paradigm. Nature Reviews Cancer, v. 13, n. 10, p. 714-726, 2013. Disponível em: < http://www.nature.com/nrc/journal/v13/n10/abs/nrc3599.html >. doi: 10.1038/nrc3599.

HOU, J., GU, Y., HOU, W., WU, S., LOU, Y., et al. P53 codon 72 polymorphism, human papillomavirus infection, and their interaction to oral carcinoma susceptibility. BMC genetics, v. 16, n. 1, p. 1, 2015. Disponível em: < https://bmcgenet.biomedcentral.com/articles/10.1186/s12863-015-0235-7 >. doi: 10.1186/s12863-015-0235-7.

ITOH, Y., MURATA, A., SAKAMOTO, S., NANATANI, K., WADA, T., et al. Activation of p53 facilitates the target search in DNA by enhancing the target recognition probability. Journal of Molecular Biology, v. 428, n. 14, p. 2916-2930, 2016. Disponível em: < http://dx.doi.org/10.1016/j.jmb.2016.06.001 >. doi: 10.1016/j.jmb.2016.06.001. 
KALE, J.; OSTERLUND, E. J.; ANDREWS, D. W. BCL-2 family proteins: changing partners in the dance towards death. Cell death and differentiation, v. 25, n. 1, p. 65, 2018. Disponível em: < https://www.nature.com/articles/cdd2017186 >. doi: 10.1038 / cdd.2017.186.

KALLENBERGER, S.; LEGEWIE, S. Modeling formalisms in systems biology of apoptosis. Systems Biology of Apoptosis, p. 1-32, 2012. Disponível em: < http://link.springer.com/chapter/10.1007/978-1-4614-4009-3_1 >. doi: 10.1007/9781-4614-4009-3_1.

KATO, S., HAN, S. Y., LIU, W., OTSUKA, K., SHIBATA, H., et al. Understanding the function-structure and function-mutation relationships of p53 tumor suppressor protein by high-resolution missense mutation analysis. Proceedings of the National Academy of Sciences, v. 100, n. 14, p. 8424-8429, 2003. Disponível em: < http://www.pnas.org/content/100/14/8424.short >. doi: 10.1073/pnas.1431692100.

KONG, C. S., CAO, H., KWOK, S., NGUYEN, C. M., JORDAN, R. C., et al. Loss of the p53/p63 target PERP is an early event in oral carcinogenesis and correlates with higher rate of local relapse. Oral surgery, oral medicine, oral pathology and oral radiology, v. 115, n. 1, p. 95-103, 2013. Disponível em: < http://dx.doi.org/10.1016/j.000o.2012.10.017 >. doi: 10.1016/j.0000.2012.10.017.

LANGLAIS, C.; HUGHES, M. A.; CAIN, K.; MACFARLANE, M. Biochemical Analysis of Initiator Caspase-Activating Complexes: The Apoptosome and the Death-Inducing Signaling Complex. Cold Spring Harbor Protocols, v. 2015, n. 12, p. 1050-1052, 2015. Disponível em: < http://cshprotocols.cshlp.org/content/2015/12/pdb.top070326.short >. doi: 10.1101/pdb.top070326.

LEE, J.-H.; CHO, H.-D.; JEONG, I.-Y.; LEE, M.-K.; SEO, K.-I. Sensitization of tumor necrosis factor-related apoptosis-inducing ligand (TRAIL)-resistant primary prostate cancer cells by isoegomaketone from Perilla frutescens. Journal of natural products, v. $77, \quad$ n. 11, p. 2438-2443, 2014. Disponível em: < http://pubs.acs.org/doi/abs/10.1021/np500452e >. doi: 10.1021/np500452e.

LI, J. P., YANG, Y. X., LIU, Q. L., PAN, S. T., HE, Z. X., et al. The investigational Aurora kinase A inhibitor alisertib (MLN8237) induces cell cycle G2/M arrest, apoptosis, and autophagy via p38 MAPK and Akt/mTOR signaling pathways in human breast cancer cells. Drug design, development and therapy, v. 9, p. 1627, 2015. Disponível em: < http://dx.doi.org/10.2147/dddt.s75378 >. doi: 10.2147/dddt.s75378.

LIU, F.-T.; NEWLAND, A. C.; JIA, L. Bax conformational change is a crucial step for PUMA-mediated apoptosis in human leukemia. Biochemical and biophysical research communications, v. 310, n. 3, p. 956-962, 2003. Disponível em: < http://dx.doi.org/10.1016/j.bbrc.2003.09.109 >. doi: 10.1016/j.bbrc.2003.09.109.

LIU, J.; ZHANG, C.; FENG, Z. Tumor suppressor p53 and its gain-of-function mutants in cancer. Acta biochimica et biophysica Sinica, v. 46, n. 3, p. 170-179, 
2014. Disponível em: < http://abbs.oxfordjournals.org/content/46/3/170.short >. doi: 10.1093/abbs/gmt144.

LIU, L.; WONG, C.; GONG, B.; YU, J. Functional significance and therapeutic implication of ring-type E3 ligases in colorectal cancer. Oncogene, v. 37, n. 2, p. 148, 2018. Disponível em: < https://www.nature.com/articles/onc2017313 >. doi: 10.1038 / onc.2017.313.

LOWE, S. W.; SCHMITT, E. M.; SMITH, S. W.; OSBORNE, B. A.; JACKS, T. p53 is required for radiation-induced apoptosis in mouse thymocytes. Nature, v. 362, n. 6423, p. 847-849, 1993. Disponível em: < http://www.nature.com/nature/journal/v362/n6423/abs/362847a0.html >. doi: 10.1038/362847a0.

LUBET, R. A.; ZHANG, Z.; WISEMAN, R. W.; YOU, M. Use of p53 transgenic mice in the development of cancer models for multiple purposes. Experimental lung research, v. 26, n. 8, p. 581-593, 2000. Disponível em: < http://www.tandfonline.com/doi/abs/10.1080/01902140150216684 >. doi: 10.1080/01902140150216684.

MACEDO, G. S., VIEIRA, I. A., BRANDALIZE, A. P., GIACOMAZZI, J., PALMERO, E. I., et al. Rare germline variant (rs78378222) in the TP53 3'UTR: Evidence for a new mechanism of cancer predisposition in Li-Fraumeni syndrome. Cancer genetics, v. 209, n. 3, p. 97-106, 2016. Disponível em: < http://dx.doi.org/10.1016/j.cancergen.2015.12.012 >. doi: 10.1016/j.cancergen.2015.12.012.

MAES, M. E.; SCHLAMP, C. L.; NICKELLS, R. W. Live-cell imaging to measure BAX recruitment kinetics to mitochondria during apoptosis. PloS one, v. 12, n. 9, p. e0184434, 2017. Disponível em: < https://journals.plos.org/plosone/article?id=10.1371/journal.pone.0184434 >. doi: 10.1371/journal.pone.0184434.

MAZELIN, L., PANTHU, B., NICOT, A. S., BELOTTI, E., TINTIGNAC, L., et al. mTOR inactivation in myocardium from infant mice rapidly leads to dilated cardiomyopathy due to translation defects and p53/JNK-mediated apoptosis. Journal of molecular and cellular cardiology, v. 97, n. 1, p. 213-225, 2016. Disponível em: < http://dx.doi.org/10.1016/j.yjmcc.2016.04.011 >. doi: 10.1016/j.yjmcc.2016.04.011.

MAZZONI, C.; FALCONE, C. Caspase-dependent apoptosis in yeast. Biochimica et Biophysica Acta (BBA)-Molecular Cell Research, v. 1783, n. 7, p. 1320-1327, 2008. Disponível em: < http://dx.doi.org/10.1016/j.bbamcr.2008.02.015 >. doi: 10.1016/j.bbamcr.2008.02.015.

MCILWAIN, D. R.; BERGER, T.; MAK, T. W. Caspase functions in cell death and disease. Cold Spring Harbor perspectives in biology, v. 5, n. 4, p. 1-28, 2013. Disponível em: < http://cshperspectives.cshlp.org/content/5/4/a008656.short >. doi: 10.1101/cshperspect.a008656. 
MEISTER, M. T., BOEDICKER, C., GRAAB, U., HUGLE, M., HAHN, H., et al. Arsenic trioxide induces Noxa-dependent apoptosis in rhabdomyosarcoma cells and synergizes with antimicrotubule drugs. Cancer Letters, 2016. Disponível em: < http://dx.doi.org/10.1016/j.canlet.2016.07.007 >. doi: 10.1016/j.canlet.2016.07.007.

MICIAK, J.; BUNZ, F. Long story short: p53 mediates innate immunity. Biochimica et Biophysica Acta (BBA)-Reviews on Cancer, v. 1865, n. 2, p. 220-227, 2016. Disponível em:

http://www.sciencedirect.com/science/article/pii/S0304419X16300233 >. doi: 10.1016/j.bbcan.2016.03.001.

MONTEITH, J. A., MELLERT, H., SAMMONS, M. A., KUSWANTO, L. A., SYKES, S. M., et al. A rare DNA contact mutation in cancer confers p53 gain-of-function and tumor cell survival via TNFAIP8 induction. Molecular Oncology, 2016. Disponível em: < https://febs.onlinelibrary.wiley.com/doi/abs/10.1016/j.molonc.2016.05.007 >. doi: 10.1016/j.molonc.2016.05.007.

MOYA, A., SAKAMAKI, K., MASON, B. M., HUISMAN, L., FORÊT, S., et al. Functional conservation of the apoptotic machinery from coral to man: the diverse and complex Bcl-2 and caspase repertoires of Acropora millepora. BMC genomics, v. 17, n. 1, p. 1, 2016. Disponível em: < http://bmcgenomics.biomedcentral.com/articles/10.1186/s12864-015-2355-x >. doi: 10.1186/s12864-015-2355-x.

MULLER, P. A.; VOUSDEN, K. H. p53 mutations in cancer. Nature cell biology, v. $15, \quad$ n. $1, \quad$ p. 2-8, 2013. Disponível em: < http://www.nature.com/ncb/journal/v15/n1/abs/ncb2641.html >. doi: 10.1038/ncb2641.

MULLER, P. A.; VOUSDEN, K. H. Mutant p53 in cancer: new functions and therapeutic opportunities. Cancer cell, v. 25, n. 3, p. 304-317, 2014. Disponível em: < http://dx.doi.org/10.1016/j.ccr.2014.01.021 >. doi: 10.1016/j.ccr.2014.01.021.

NIHIRA, N. T., OGURA, K., SHIMIZU, K., NORTH, B. J., ZHANG, J., et al. Acetylation-dependent regulation of MDM2 E3 ligase activity dictates its oncogenic function. Sci. Signal., v. 10, n. 466, p. eaai8026, 2017. Disponível em: < http://stke.sciencemag.org/content/10/466/eaai8026 >. doi: 10.1126/scisignal.aai8026.

ODA, E., OHKI, R., MURASAWA, H., NEMOTO, J., SHIBUE, T., et al. Noxa, a BH3-only member of the Bcl-2 family and candidate mediator of p53-induced apoptosis. Science, v. 288, n. 5468, p. 1053-1058, 2000. Disponível em: < http://science.sciencemag.org/content/288/5468/1053 $\quad$. doi: 10.1126/science.288.5468.1053.

PAGLIARONE, S.; FRATTONE, L.; PIROCCHI, V.; DELLA SALDA, L.; PALMIERI, C. Altered expression of $\mathrm{p53}$, but not $\mathrm{Rb}$, is involved in canine prostatic carcinogenesis. Research in veterinary science, v. 105, n. 1, p. 195-199, 2016. Disponível em: < http://dx.doi.org/10.1016/j.rvsc.2016.02.022 >. doi: 10.1016/j.rvsc.2016.02.022. 
PANT, V.; LOZANO, G. Dissecting the p53-Mdm2 feedback loop in vivo: uncoupling the role in p53 stability and activity. Oncotarget, v. 5, n. 5, p. 1149-1156, 2014. Disponível em: < http://www.ncbi.nlm.nih.gov/pmc/articles/PMC4012731/ >. doi: 10.18632/oncotarget.1797.

PEIXOTO, P. M., TEIJIDO, O., MIRZALIEVA, O., DEJEAN, L. M., PAVLOV, E. V., et al. MAC inhibitors antagonize the pro-apoptotic effects of tBid and disassemble Bax/Bak oligomers. Journal of bioenergetics and biomembranes, p. 1-10, 2015. Disponível em: < http://link.springer.com/article/10.1007/s10863-015-9635-7 >. doi: 10.1007/s10863-015-9635-7.

REDZA-DUTORDOIR, M.; AVERILL-BATES, D. A. Activation of apoptosis signalling pathways by reactive oxygen species. Biochimica et Biophysica Acta (BBA)Molecular Cell Research, v. 1863, n. 12, p. 2977-2992, 2016. Disponível em: < https://www.sciencedirect.com/science/article/pii/S0167488916302324 >. doi: 10.1016/j.bbamcr.2016.09.012.

RENAULT, T. T., FLOROS, K. V., ELKHOLI, R., CORRIGAN, K. A., KUSHNAREVA, $Y$., et al. Outer mitochondrial membrane shape engages BAX $\alpha 9$ to initiate mitochondrial outer membrane permeabilization and apoptosis. Molecular cell, v. 57, n. 1, p. 69, 2015. Disponível em: < http://dx.doi.org/10.1016/j.molcel.2014.10.028 >. doi: $10.1016 /$ j.molcel.2014.10.028.

RETZLAFF, M., ROHRBERG, J., KÜPPER, N. J., LAGLEDER, S., BEPPERLING, A., et al. The regulatory domain stabilizes the p53 tetramer by intersubunit contacts with the DNA binding domain. Journal of molecular biology, v. 425, n. 1, p. 144-155, 2013. Disponível em: < http://dx.doi.org/10.1016/j.jmb.2012.10.015 >. doi: 10.1016/j.jmb.2012.10.015.

SCHULZ-HEDDERGOTT, R.; MOLL, U. Gain-of-Function (GOF) Mutant p53 as Actionable Therapeutic Target. Cancers, v. 10, n. 6, p. 188, 2018. Disponível em: < http://www.mdpi.com/2072-6694/10/6/188 >. doi: 10.3390/cancers10060188.

SHAPIRO, E.; BIEZUNER, T.; LINNARSSON, S. Single-cell sequencing-based technologies will revolutionize whole-organism science. Nature Reviews Genetics, v. $14, \quad$ n. 9 , p. 618-630, 2013. Disponível em: < http://www.nature.com/nrg/journal/v14/n9/abs/nrg3542.html >. doi: 10.1038/nrg3542.

SUBBURAJ, Y., COSENTINO, K., AXMANN, M., PEDRUEZA-VILLALMANZO, E., HERMANN, E., et al. Bax monomers form dimer units in the membrane that further self-assemble into multiple oligomeric species. Nature communications, v. 6, p. 111, 2015. Disponível em: < http://www.nature.com/articles/ncomms9042 >. doi: $10.1038 /$ ncomms 9042.

SUVÀ, M. L.; RIGGI, N.; BERNSTEIN, B. E. Epigenetic reprogramming in cancer. Science, v. $339, \quad$ n. $6127, \quad$ p. 1567-1570, 2013. Disponível em: < http://dx.doi.org/10.1126/science.1230184 >. doi: 10.1126/science.1230184.

WADE, M.; LI, Y.-C.; WAHL, G. M. MDM2, MDMX and p53 in oncogenesis and cancer therapy. Nature Reviews Cancer, v. 13, n. 2, p. 83-96, 2013. Disponível em: 
< http://www.nature.com/nrc/journal/v13/n2/abs/nrc3430.html >. doi: 10.1038/nrc3430.

WALENSKY, L. D.; GAVATHIOTIS, E. BAX unleashed: the biochemical transformation of an inactive cytosolic monomer into a toxic mitochondrial pore. Trends in biochemical sciences, v. 36, n. 12, p. 642-652, 2011. Disponível em: < http://dx.doi.org/10.1016/j.tibs.2011.08.009 >. doi: 10.1016/j.tibs.2011.08.009.

WANG, X., SHAO, C., WANG, L., LI, Q., SONG, H., et al. The viral non-structural protein 1 alpha $(\mathrm{Nsp} 1 \alpha)$ inhibits p53 apoptosis activity by increasing murine double minute 2 (mdm2) expression in porcine reproductive and respiratory syndrome virus (PRRSV) early-infected cells. Veterinary microbiology, v. 184, p. 73-79, 2016. Disponível em: < http://dx.doi.org/10.1016/j.vetmic.2016.01.009 >. doi: 10.1016/j.vetmic.2016.01.009.

WATANABE, M.; MOON, K. D.; VACCHIO, M. S.; HATHCOCK, K. S.; HODES, R. J. Downmodulation of tumor suppressor $\mathrm{p} 53$ by $\mathrm{T}$ cell receptor signaling is critical for antigen-specific CD4+ T cell responses. Immunity, v. 40, n. 5, p. 681-691, 2014. Disponível em: < http://dx.doi.org/10.1016/j.immuni.2014.04.006 >. doi: 10.1016/j.immuni.2014.04.006.

WEBER, A. M.; RYAN, A. J. ATM and ATR as therapeutic targets in cancer. Pharmacology \& therapeutics, v. 149, p. 124-138, 2015. Disponível em: < http://dx.doi.org/10.1016/j.pharmthera.2014.12.001 >. doi: 10.1016/j.pharmthera.2014.12.001.

WEI, C. L., WU, Q., VEGA, V. B., CHIU, K. P., NG, P., et al. A global map of p53 transcription-factor binding sites in the human genome. Cell, v. 124, n. 1, p. 207-219, 2006. Disponível em: < http://dx.doi.org/10.1016/j.cell.2005.10.043 >. doi: 10.1016/j.cell.2005.10.043.

WOODS, S. J.; HANNAN, K. M.; PEARSON, R. B.; HANNAN, R. D. The nucleolus as a fundamental regulator of the p53 response and a new target for cancer therapy. Biochimica et Biophysica Acta (BBA)-Gene Regulatory Mechanisms, v. 1849, n. 7, p. 821-829, 2015. Disponível em: < http://dx.doi.org/10.1016/j.bbagrm.2014.10.007 >. doi: 10.1016/j.bbagrm.2014.10.007.

YU, J.; ZHANG, L. PUMA, a potent killer with or without p53. Oncogene, v. 27, p. S71-S83, $2008 . \quad$ Disponível em: < http://www.nature.com/onc/journal/v27/n1s/full/onc200945a.html >. doi: 10.1038/onc.2009.45.

YUE, X., ZHAO, Y., XU, Y., ZHENG, M., FENG, Z., et al. Mutant p53 in cancer: accumulation, gain-of-function, and therapy. Journal of molecular biology, v. 429, n. 11, p. 1595-1606, 2017. Disponível em: < https://www.sciencedirect.com/science/article/pii/S0022283617301638 >. doi: 10.1016/j.jmb.2017.03.030. 
ZHANG, Y.; ZHANG, Q.; ZENG, S. X.; HAO, Q.; LU, H. Inauhzin sensitizes p53dependent cytotoxicity and tumor suppression of chemotherapeutic agents. Neoplasia, v. 15, n. 5, p. 523-34, 2013. Disponível em: < http://dx.doi.org/10.1593/neo.13142 >. doi: 10.1593/neo.13142 